\title{
Development of severe acute respiratory syndrome coronavirus 2 (SARS-CoV-2) thermal inactivation method with preservation of diagnostic sensitivity
}

\author{
Young-Il Kim ${ }^{1,2 \dagger}$, Mark Anthony B. Casel ${ }^{1,2 \dagger}$, \\ Se-Mi Kim ${ }^{1}$, Seong-Gyu Kim ${ }^{1}$, Su-Jin Park ${ }^{1,2}$, \\ Eun-Ha Kim ${ }^{1,2}$, Hye Won Jeong ${ }^{1}$, \\ Haryoung $\mathrm{Poo}^{3}$, and Young Ki Choi ${ }^{1,2 \star}$ \\ ${ }^{1}$ College of Medicine and Medical Research Institute, \\ Chungbuk National University, Cheongju 28644, Republic of Korea \\ ${ }^{2}$ Zoonotic Infectious Diseases Research Center, Chungbuk National \\ University, Cheongju 28644, Republic of Korea \\ ${ }^{3}$ Infectious Disease Research Center, Korea Research Institute of \\ Bioscience and Biotechnology, University of Science and Technology, \\ Daejeon 34141, Republic of Korea \\ (Received Jul 1, 2020 / Revised Aug 18, 2020 / Accepted Aug 19, 2020)
}

Various treatments and agents had been reported to inactivate RNA viruses. Of these, thermal inactivation is generally considered an effective and cheap method of sample preparation for downstream assays. The purpose of this study is to establish a safe inactivation method for SARS-CoV-2 without compromising the amount of amplifiable viral genome necessary for clinical diagnoses. In this study, we demonstrate the infectivity and genomic stability of SARS$\mathrm{CoV}-2$ by thermal inactivation at both $56^{\circ} \mathrm{C}$ and $65^{\circ} \mathrm{C}$. The results substantiate that viable SARS-CoV-2 is readily inactivated when incubated at $56^{\circ} \mathrm{C}$ for $30 \mathrm{~min}$ or at $65^{\circ} \mathrm{C}$ for $10 \mathrm{~min}$. qRT-PCR of specimens heat-inactivated at $56^{\circ} \mathrm{C}$ for $30 \mathrm{~min}$ or $65^{\circ} \mathrm{C}$ for $15 \mathrm{~min}$ revealed similar genomic RNA stability compared with non-heat inactivated specimens. Further, we demonstrate that $30 \mathrm{~min}$ of thermal inactivation at $56^{\circ} \mathrm{C}$ could inactivate viable viruses from clinical COVID-19 specimens without attenuating the QRT-PCR diagnostic sensitivity. Heat treatment of clinical specimens from COVID-19 patients at $56^{\circ} \mathrm{C}$ for $30 \mathrm{~min}$ or $65^{\circ} \mathrm{C}$ for $15 \mathrm{~min}$ could be a useful method for the inactivation of a highly contagious agent, SARS-CoV-2. Use of this method would reduce the potential for secondary infections in BSL2 conditions during diagnostic procedures. Importantly, infectious virus can be inactivated in clinical specimens without compromising the sensitivity of the diagnostic RT-PCR assay.

Keywords: SARS-CoV-2, heat inactivation, COVID-19, genomic stability, RT-PCR

\footnotetext{
${ }^{\dagger}$ These authors contributed equally to this work.

*For correspondence. E-mail: choiki55@chungbuk.ac.kr; Tel.: +82-43-261-

3384; Fax: +82-43-273-3252

Copyright (c) 2020, The Microbiological Society of Korea
}

\section{Introduction}

Corona Virus Disease 2019 (COVID-19) is an infectious disease caused by a novel coronavirus, Severe Acute Respiratory Syndrome 2 (SARS-CoV-2). SARS-CoV-2, temporarily named 2019 novel coronavirus (2019-nCoV) by the World Health Organization on January 7, 2020, is a positive-sense single-stranded RNA virus belonging to genus Betacoronavirus, which has distinct genetic characteristics from SARSCoV and MERS-CoV (Huang et al., 2020; WHO, 2020b). Due to the highly contagious nature of SARS-CoV-2, COVID-19 was designated a Public Health Emergency of International Concern by the World Health Organization (WHO) on January 30,2020, and officially declared a pandemic on March 11, 2020 (WHO, 2020a, 2020c). As of August 12, 2020, there have been 20,330,351 confirmed cases and 742,413 case fatalities due to respiratory failure or other complications associated with this infection (ECDC, 2020). Although most people infected with SARS-CoV-2 suffer from mild to moderate respiratory illness and recover without requiring special treatment, patients with chronic health problems and immunocompromised conditions are more likely to develop serious illness, including mortality (Chan et al., 2020).

Coronaviruses are known to be fragile and are vulnerable to heat (Lelie et al., 1987; Lamarre and Talbot, 1989; Schlegel et al., 2001), but appear to be stable at $4^{\circ} \mathrm{C}$ (Lamarre and Talbot, 1989; Pratelli, 2008). Thermal inactivation of viruses is directly related to the chemical composition of these microbes and involves disruption of the sugar-phosphate backbone or denaturation of the viral protein particle (Knight, 1975; Siddell et al., 1983; Nuanualsuwan and Cliver, 2003; Decrey et al., 2016; McDonnell, 2017). For the inactivation of highly pathogenic viruses, the Pan American Health Organization recommends that serum samples or other organic fluids be incubated at $60^{\circ} \mathrm{C}$ for $60 \mathrm{~min}$. Therefore, this procedure has been adopted by many laboratories for the handling of highly pathogenic virus specimens (Pratelli, 2008; PAHO, 2020a, 2020b). Since many coronaviruses are sensitive to thermal inactivation, the WHO recommended that SARS-CoV specimens be placed at $56^{\circ} \mathrm{C}$ for 15 to $45 \mathrm{~min}$ for viable virus inactivation (WHO, 2003), a recommendation that can be adapted to heat inactivate SARS-CoV-2. In addition, other studies have suggested incubation at $65^{\circ} \mathrm{C}$ for $10 \mathrm{~min}$ is required for full inactivation of coronaviruses (Pratelli, 2008; PAHO, 2020a). Although $56^{\circ} \mathrm{C}$ and $65^{\circ} \mathrm{C}$ are commonly used temperatures for inactivation of enveloped viruses (Roehrig et al., 2008; Cutts et al., 2016; Park et al., 2016), the difference in recommended temperature requirements 
Table 1. Primer set specific for SARS-CoV-2 ORF1a, Spike, E gene, and N gene

\begin{tabular}{cll}
\hline & \multicolumn{1}{c}{ Forward sequence $\left(5^{\prime}-3^{\prime}\right)$} & \multicolumn{1}{c}{ Reverse sequence $\left(5^{\prime}-3^{\prime}\right)$} \\
\hline ORF1a & CCC TGT GGG TTT TAC ACT TAA & ACG ATT GTG CAT CAG CTG A \\
S & ATT CAA GAC TCA CTT TCT TCC ACA & TGT TTA AAG CTT GTG CAT TTT GGT TGA CC \\
E & GTT GAT GAG CCT GAA GAA CAT GTC C & CGT ACC TGT CTC TTC CGA AAC G \\
$\mathrm{N}$ & GTC AAG CCT CTT CTC GTT CC & GAA GCG CTG GGG GCA AAT TG \\
\hline
\end{tabular}

is dependent on the type of sample and type of analysis to be completed after inactivation. However, the RNA stability in SARS-CoV-2 specimens after this heat inactivation has not been investigated in detail.

Given the rapid, worldwide geographic spread of COVID19 , rapid analysis of large numbers of clinical specimens for SARS-CoV-2 diagnosis could increase the chances of nosocomial transmission in diagnostic laboratories. Therefore, methods for the safe inactivation of SARS-CoV-2 in clinical specimens are essential to reduce any potential secondary transmission during diagnostic procedures; however, care must be taken not to affect diagnostic sensitivity. In this study, we establish thermal inactivation procedures for SARS-CoV-2 at two different temperatures $\left(56^{\circ} \mathrm{C}\right.$ and $\left.65^{\circ} \mathrm{C}\right)$ and compare the physical stability of the RNA genome by amplifying the ORF1a, Spike, N, and E genes of heat-inactivated samples and comparing with non-treated clinical specimens.

\section{Materials and Methods}

\section{Viruses and cell line}

As a reference strain, we adapted a SARS-CoV-2 human isolate, CBNU-nCoV01 (S lineage, GISAID accession number: EPI_ISL_507039), which was isolated from a COVID-19 patient at Chungbuk National University, and the virus was grown in Vero cells (Cat\# ATCC CCL-81) as previously described (Kim et al., 2020). Briefly, Vero cells were maintained in Dulbecco's Modified Eagle's Medium (DMEM) (SigmaAldrich) and supplemented with 10\% fetal bovine serum (FBS) containing antibiotics (Gibco). When approximately $75 \%$ of the cell monolayer of a virus-infected flask showed the cytopathic effect (CPE), culture supernatant was harvested and stored at $-80^{\circ} \mathrm{C}$ until thawed for use followed by centrifugation at $12,000 \mathrm{rpm}$ for $10 \mathrm{~min}$ at $4^{\circ} \mathrm{C}$ to remove cell debris.

\section{Determination of $50 \%$ tissue culture infectious dose $\left(\mathrm{TCID}_{50}\right)$}

Confluent Vero cell monolayers were grown on 96-well microtiter plates were infected with $50 \mu \mathrm{l}$ of 10 -fold serial dilutions of the stock virus in DMEM starting from $10^{-1}$ to $10^{-8}$. Infected cells were incubated at $37^{\circ} \mathrm{C}$ with $5 \% \mathrm{CO}_{2}$ for 4 days. The appearance of $\mathrm{CPE}$ was recorded daily and the TCID $_{50}$ was determined according to the method of Reed and Muench (Reed and Muench, 1938). Titrations were done in replicates of three. Following the WHO recommendations, all work involving infectious SARS-CoV-2 was performed under biosafety level (BSL)-3 conditions in a BSL-3 facility.

\section{Physical inactivation of SARS-CoV-2 and infectivity deter- mination}

Virus infectivity was assessed by performing virus titrations after heat inactivation treatments. To assess the efficiency of thermal inactivation, $0.5 \mathrm{ml}$ supernatant from cell culture was used for the inactivation assay. The virus culture stock with a titer of $10^{5.5} \mathrm{TCID}_{50} / \mathrm{ml}$ was subjected to two temperatures $\left(56^{\circ} \mathrm{C}\right.$ and $\left.65^{\circ} \mathrm{C}\right)$ using a heating block (DAIHAN Heating-Block, Maxtable H10) over different time periods (10 $\mathrm{min}, 15 \mathrm{~min}, 30 \mathrm{~min}, 60 \mathrm{~min}$, and $120 \mathrm{~min}$ ). The temperature in the tubes was monitored with a thermometer placed in the same amount of DMEM in a separate tube. Virus specimens from each treatment condition were used to infect a monolayer of Vero cells to evaluate the viral titer by $\mathrm{TCID}_{50}$. All experiments were repeated at least three times under the same conditions.

\section{Validation of nucleic acid stability after heat inactivation}

To test whether the heat inactivation would degrade SARSCoV-2 viral RNA, total RNA was extracted from $0.2 \mathrm{ml}$ of each thermally inactivated SARS-CoV-2 sample using Qiagen Viral RNA Mini Kit (Qiagen) according to manufacturer's guideline. The viral RNA titers were quantified by Real-Time qRT-PCR as previously described (Kim et al., 2020) using primer sets specific (Table 1) for ORF1a, Spike, N, and Egene (Corman et al., 2020; Li et al., 2020) and the SYBR Green kit (iQTM SYBR Green supermix kit, Bio-Rad). The viral RNA copy number was calculated as previously described (Kim et al., 2020).

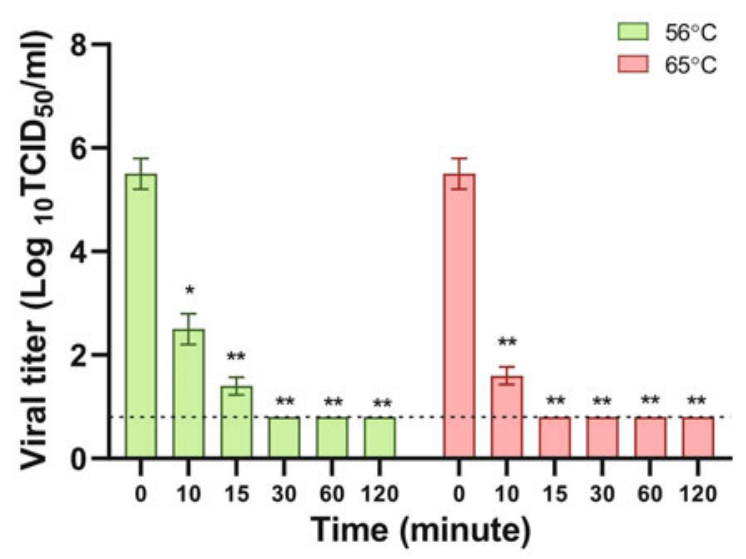

Fig. 1. Viral titer in cells of SARS-CoV-2 according to heat inactivated conditions. The mean viral titers $\left(\mathrm{TCID}_{50} / \mathrm{ml}\right)$ obtained after inactivation of cell culture supernatants with $10^{5.5} \mathrm{TCID}_{50} / \mathrm{ml}$ of SARS-CoV-2 at time zero. The titers shown are means \pm SD from three independently performed thermal inactivation at $56^{\circ} \mathrm{C}$ and $65^{\circ} \mathrm{C}$ on different time points $(10 \mathrm{~min}$, $15 \mathrm{~min}, 30 \mathrm{~min}, 60 \mathrm{~min}$, and $120 \mathrm{~min}$ ) and non-detection corresponds to titers below the limit of detection $\left(0.8 \log _{10} \mathrm{TCID}_{50} / \mathrm{ml}\right)$ (dashed lines). Green bars indicate viral titers from samples inactivated at $56^{\circ} \mathrm{C}$ and the red bars indicates viral titers from samples inactivated at $65^{\circ} \mathrm{C}$. $\left({ }^{*} p<\right.$ 0.001 and $\left.{ }^{* *} p<0.0001\right)$ 


\section{Heat inactivation and measurement of viral titers in clinical COVID-19 specimens}

Clinical COVID-19 specimens $(\mathrm{n}=40)$ were collected from the National Medical Center and Chungbuk National University hospital from March to May 25, 2020. Furthermore, negative samples $(\mathrm{n}=10)$ and unknown samples $(\mathrm{n}=16)$ were added for sensitivity and specificity evaluation of the procedure. Each specimen was divided into two separate tubes; one was stored at $4^{\circ} \mathrm{C}$ (the no heat inactivation control), and the other one was incubated at $56^{\circ} \mathrm{C}$ in a thermal block for $30 \mathrm{~min}$. Following heat inactivation procedure, specimens were subjected to qRT-PCR to compare cycle thresholds among treatments.

\section{Statistical analysis}

Data are presented as mean \pm standard deviation (SD). Unpaired two-tailed t-tests were used to analyze the differences between paired samples in inactivated and non-inactivated samples. P-values less than 0.05 were considered statistically significant.

\section{Results}

\section{Effect of thermal inactivation on viral infectivity}

To clarify the temperature sensitivity of SARS-CoV-2, we evaluated the viable viral titers in Vero cells following treatment of $10^{5.5} \mathrm{TCID}_{50} / \mathrm{ml}$ SARS-CoV-2 with two different temperatures.

As shown in Fig. 1, heat treatment of SARS-Cov- 2 at $56^{\circ} \mathrm{C}$ or $65^{\circ} \mathrm{C}$ for $30 \mathrm{~min}$ resulted in a rapid reduction of the viral infectivity titer below the detection limit. In detail, the CBNUnCoV01 showed an observable decrease, from its original viral titer of $10^{5.5} \mathrm{TCID}_{50} / \mathrm{ml}$ to $10^{2.5} \mathrm{TCID}_{50} / \mathrm{ml}$, in infectivity with as little as $10 \mathrm{~min}$ of heat inactivation at $56^{\circ} \mathrm{C}$, and the viability of the virus was maintained even after $15 \mathrm{~min}$ of heat exposure although the viral titer was as low as $10^{1.5} \mathrm{TCID}_{50} / \mathrm{ml}$. However, no viable virus was detected in the specimens treated for $30 \mathrm{~min}$. At $65^{\circ} \mathrm{C}$, the initial viral titer of $10^{5.5} \mathrm{TCID}_{50} / \mathrm{ml}$ dropped to $10^{1.5} \mathrm{TCID}_{50} / \mathrm{ml}$ after $10 \mathrm{~min}$ of heat incubation and viable CBNU-nCoV01 was not detected after 15 min of heat inactivation. This result demonstrates that SARS-CoV-2 is fully inactivated when incubated at $56^{\circ} \mathrm{C}$ or $65^{\circ} \mathrm{C}$ for 30 min or $15 \mathrm{~min}$, respectively. A rapid decline in viral infectivity of SARS-CoV-2 was observed at the higher temper-
(A)

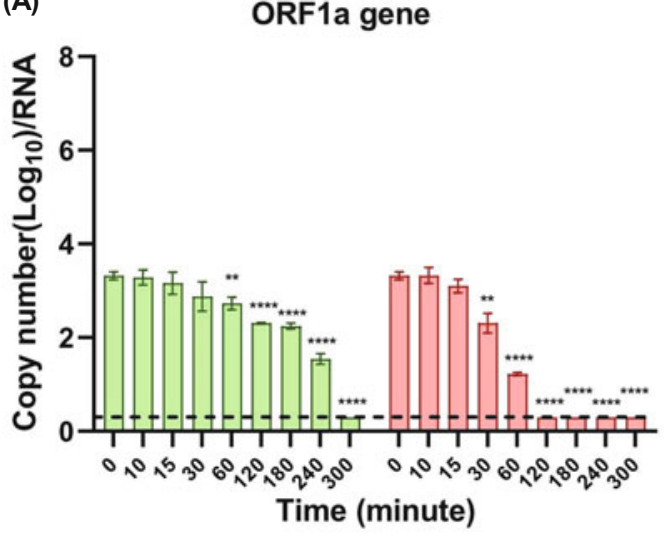

(C)

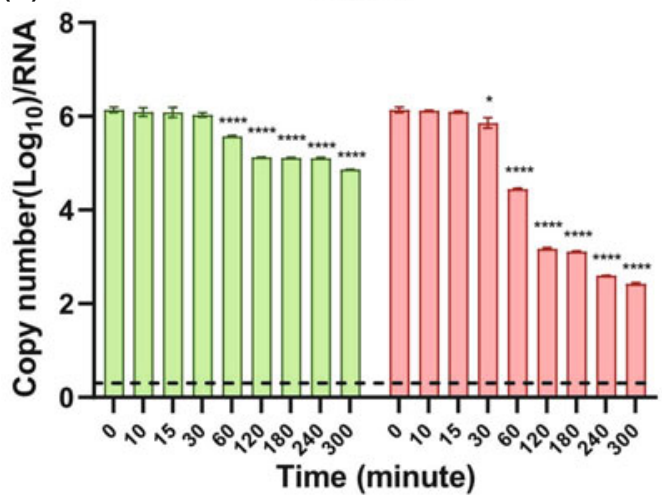

(B)
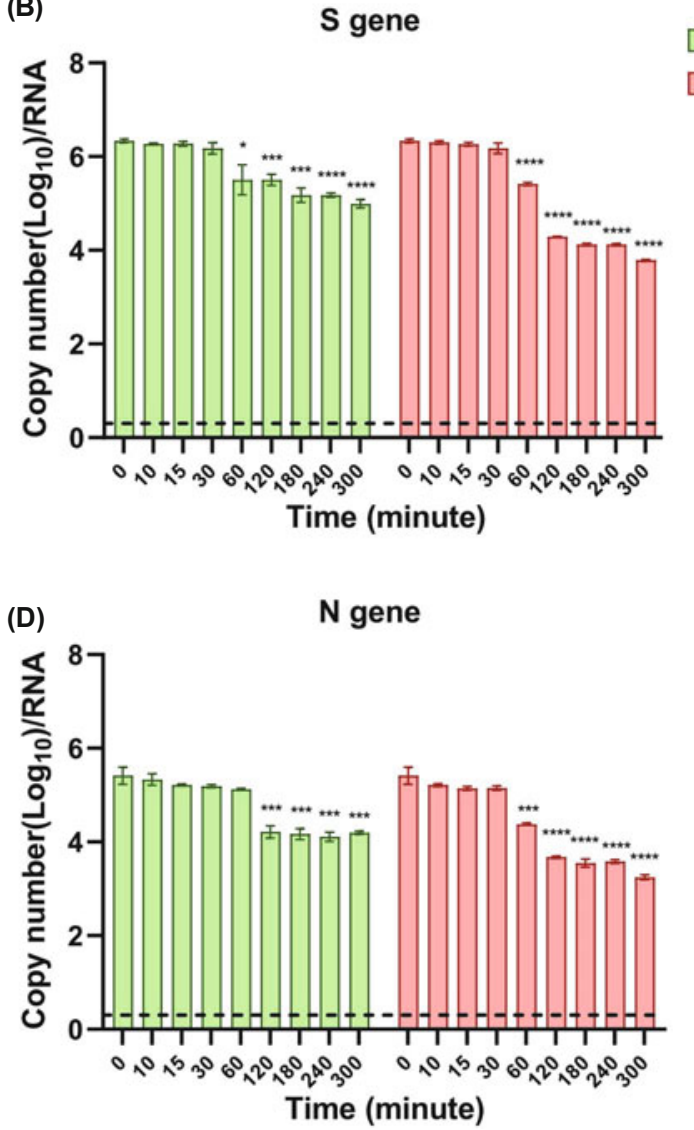

Fig. 2. Quantitative PCR value of SARS-CoV-2 according to heat inactivated conditions. Comparison of mean copy numbers (Log 10 )/RNA of ORF1a (A), Spike gene (B), E gene (C), and $\mathrm{N}$ gene (D) from samples inactivated at $56^{\circ} \mathrm{C}$ and $65^{\circ} \mathrm{C}$ on different time periods. Green bars indicate copy numbers from samples inactivated at $56^{\circ} \mathrm{C}$ and the red bars indicates copy numbers from samples inactivated at $65^{\circ} \mathrm{C}$. The copy numbers shown are means \pm SD from three independently performed experiments and titers below the limit of detection are shown as $0.3 \log _{10}$ viral RNA copy numbers ( ${ }^{2}$ ashed lines). ${ }^{*} p<$ $0.05,{ }^{* *} p<0.01,{ }^{* * *} p<0.001$, and $\left.{ }^{* * *} p<0.0001\right)$ 
Table 2. Virus isolation on COVID-19 clinical specimens before and after heat inactivation $\left(56^{\circ} \mathrm{C}\right.$ for $\left.30 \mathrm{~min}\right)$

\begin{tabular}{lcc}
\hline & Positive samples $(\mathrm{n}=40)$ & Negative sample $(\mathrm{n}=10)$ \\
\hline Number of isolated virus/ naïve samples & $18 / 40$ & $0 / 10$ \\
Number of isolated virus/ heat inactivated samples & $0 / 40$ & $0 / 10$ \\
\hline
\end{tabular}

ature $\left(65^{\circ} \mathrm{C}\right)$, while a more gradual decrease in infectivity was seen with heat inactivation at $56^{\circ} \mathrm{C}$.

\section{Effect of heat inactivation on nucleic acid stability}

To test whether heat inactivation could have a negative effect on viral RNA stability, $10^{5.5} \mathrm{TCID}_{50} / \mathrm{ml}$ of virus stock was subjected to either $56^{\circ} \mathrm{C}$ or $65^{\circ} \mathrm{C}$ in a thermal block. Following each step of heat inactivation, total RNA was extracted and qRT-PCR assays were performed to calculate the RNA copy numbers of ORF1a, S, E, and N gene segments (Fig. 2).

Heat inactivation at $56^{\circ} \mathrm{C}$ for up to $30 \mathrm{~min}$ did not cause a significant decrease in viral RNA copy numbers in comparison with the non-heat treated control for ORF1a (Fig. 2A, Green Bar), S (Fig. 2B, Green Bar), E (Fig. 2C, Green Bar), or N (Fig. 2D, Green Bar). In addition, for incubations within $30 \mathrm{~min}$ there was a mean decreased of $0.41 \log _{10}$ copies $/ \mathrm{ml}, 0.16 \log _{10}$ copies $/ \mathrm{ml}, 0.08 \log _{10}$ copies $/ \mathrm{ml}$, and $0.26 \log _{10}$ copies/ml RNA copy numbers were observed to ORF1a, S, E, and N, respectively, for every time period. The
$\mathrm{N}$ gene showed comparable RNA copy numbers with that of the non-heat treated control specimens even after $60 \mathrm{~min}$ of heat inactivation, suggesting that this gene has the highest genetic stability at $56^{\circ} \mathrm{C}$. However, there was a slight, but significant, decrease in RNA copy numbers with incubations longer than $30 \mathrm{~min}$ (Fig. 2A-D).

As for heat inactivation at $65^{\circ} \mathrm{C}$ (Fig. 2, Red Bar), there was no significant difference in viral RNA copy numbers during short incubations (10 to $15 \mathrm{~min}$ of thermal inactivation) between heat-treated and non-heat treated samples. In addition, for incubations within $15 \mathrm{~min}$ there was a mean decreased of $0.19 \log _{10}$ copies/ml, $0.07 \log _{10}$ copies/ml, $0.02 \log _{10}$ copies $/ \mathrm{ml}$, and $0.31 \log _{10}$ copies $/ \mathrm{ml}$ were observed to ORF1a, S, $\mathrm{E}$, and $\mathrm{N}$, respectively. Meanwhile, there was a significant decrease in RNA detection when samples were inactivated for more than $15 \mathrm{~min}$. Following $30 \mathrm{~min}$ of heat inactivation, decreases of approximately $2 \%, 4 \%$, and $5 \%$ were seen for the RNA copy numbers of $\mathrm{S}, \mathrm{E}$, and $\mathrm{N}$, respectively, and a significant drop of $15 \%, 27 \%$, and $20 \%$, for the S, E, and N genes occurred with $60 \mathrm{~min}$ of thermal inactivation. More-
(A)

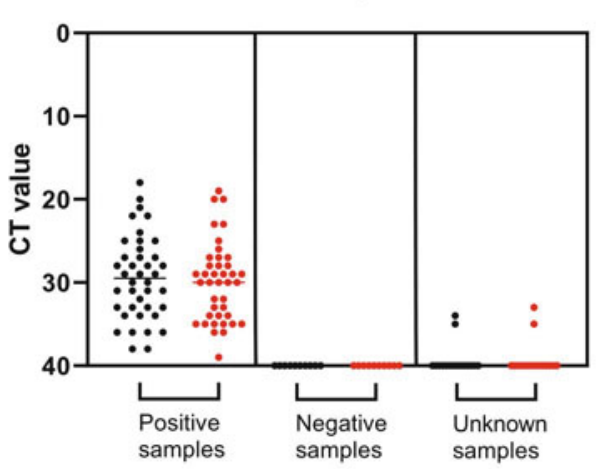

(C)

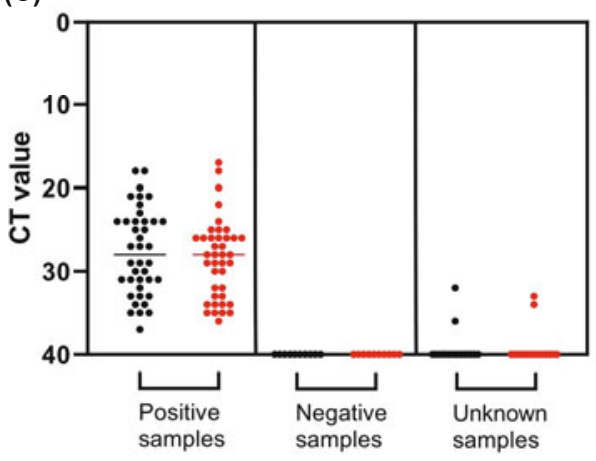

(B)

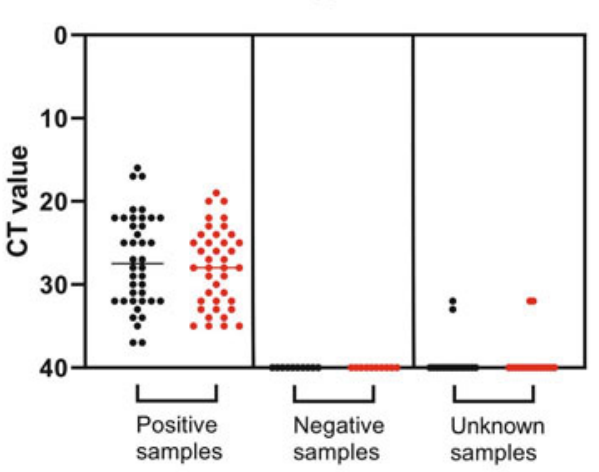

(D)

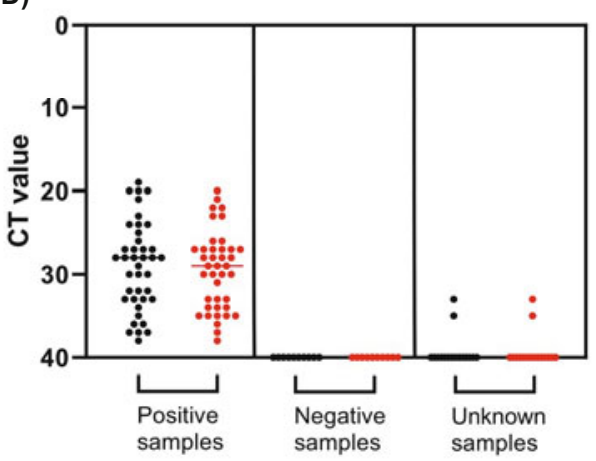

Fig. 3. The cycle threshold (Ct) value for ORF1a, $\mathrm{S}, \mathrm{N}$, and $\mathrm{E}$ gene of SARS-CoV-2 according to heat inactivation conditions in clinical samples. Comparison of cycle threshold (Ct) value of ORF1a (A), Spike gene (B), E gene (C), and N gene (D) from naïve (black) and heat inactivated specimens (red). Ct values are plotted as dots for each of the clinical specimens. The mean $\mathrm{Ct}$ value for each treatment is indicated by a horizontal bar. 
over, at 120 min of heat inactivation the ORFla gene RNA was significantly reduced below the quantification level. This data suggests that SARS-CoV-2 viral RNA remains stable when treated at $56^{\circ} \mathrm{C}$ or $65^{\circ} \mathrm{C}$ for up to $30 \mathrm{~min}$.

\section{Heat inactivation of clinical COVID-19 specimens}

We next evaluated the viability and genomic stability of SARS-CoV-2 with laboratory-confirmed COVID-19 clinical specimens. We were able to isolate SARS-CoV-2 from 18 of 40 laboratory-confirmed nasopharyngeal specimens; however, no virus was isolated from specimens incubated at $56^{\circ} \mathrm{C}$ for $30 \mathrm{~min}$ (Table 2). Nonetheless, we were able to detect ORF1a, S, N, and E genes by qRT-PCR from these thermally inactivated specimens without significant differences in $\mathrm{Ct}$ values compared with non-inactivated specimens. Further, there was positive detection of target gene segments by qRTPCR of two unknown samples with no significant difference between heat inactivated and naïve specimens. In addition, qRT-PCR on negative samples resulted in no amplification of the target gene segments in either inactivated or naïve specimens (Fig. 3). Thus, heat inactivation of COVID-19 clinical specimens at $56^{\circ} \mathrm{C}$ for 30 min successfully reduces the transmission risk, without compromising the ability to detect virus by qRT-PCR.

\section{Discussion}

Thermal inactivation of viruses occurs through denaturation of the secondary structures of viral proteins, thereby altering their conformation and function in attachment and replication within the host (Lelie et al., 1987; Schlegel et al., 2001). In addition, absorption of heat causes linked molecules to vibrate vigorously, leading to the disruption of bonding, such as in sugar-phosphate bonds, by creating nicks in the phosphodiester linkages and thus causing nucleic acid fragmentation (Knight, 1975; Siddell et al., 1983; Nuanualsuwan and Cliver, 2003; McDonnell, 2017).

In this study, we found that the SARS-CoV-2 is efficiently inactivated following incubation at $56^{\circ} \mathrm{C}$ or $65^{\circ} \mathrm{C}$ for 30 $\mathrm{min}$ or $15 \mathrm{~min}$, respectively. These results are consistent with reports of other studies on the effectiveness of subjecting biological specimens to heat in order to eliminate viral infectivity, including SARS-CoV, MERS-CoV, and human seasonal coronavirus strains (Herriott, 1961; Darnell et al., 2004; Yunoki et al., 2004; Leclercq et al., 2014; Batéjat et al., 2020). However, most of these studies were focused on virus inactivation for experimental purposes and not for use in diagnostic procedures. In this study, we demonstrate that the genomic stability of SARS-CoV-2 is maintained after $30 \mathrm{~min}$ of heat inactivation of specimens at $56^{\circ} \mathrm{C}$, as evidenced by qRT-PCR. Further, we also verified the applicability of this heat inactivation method to clinical specimens from COVID19 patients. It is noteworthy that heat inactivation of SARSCoV-2 at $56^{\circ} \mathrm{C}$ for 30 min does not alter the sensitivity of RNA detection by qRT-PCR and similar results were obtained as with non-treated clinical specimens. Therefore, this result suggests that a simple pre-incubation of clinical specimens from COVID-19 patients in a thermal block can reduce the risk of laboratory acquired infections during the handling of clinical specimens and thus greatly increase testing ability. Some intact positive-sense viral RNA genomes have been shown to act as an mRNA and thus, serve as a transcript resulting in the generation of viral proteins and genetic replication when introduced into cells under certain conditions (Larkin, 1977; Gamarnik and Andino, 1998). Thus, although we demonstrated high genetic stability of SARS-CoV-2 viral RNAs following thermal inactivation, the potential for infection by an intact, free RNA was not evaluated. Although the likelihood of such infection by intact SARS-CoV-2 RNA in diagnostic laboratory staff is very low, further cell-based studies are needed to clarify this concern.

Taken together, this study demonstrates effective inactivation of viable SARS-CoV-2 in experimental and clinical specimens by heat treatment. In addition, we also clearly demonstrate that inactivation of the virus at $56^{\circ} \mathrm{C}$ for $30 \mathrm{~min}$ improves the safety profile of clinical specimens while imparting no negative effect on the diagnostic assay for SARS-CoV2 by qRT-PCR. Thus, this simple heat inactivation method can improve conditions for molecular diagnostic testing and mitigate the risk of exposure for laboratory personnel handling highly contagious virus specimens.

\section{Acknowledgments}

This work was supported by the Korea Research Institute of Bioscience and Biotechnology (KRIBB) Research Initiative Program (KGM9942011) and conducted during the research year of Chungbuk National University in 2018 for Young Ki Choi.

\section{Conflict of Interest}

The authors have declared that no conflict of interest exists.

\section{References}

Batéjat, C., Grassin, Q., Manuguerra, J.C., and Leclercq, I. 2020. Heat inactivation of the severe acute respiratory syndrome coronavirus 2. bioRxiv 067769.

Chan, J.F.W., Yuan, S., Kok, K.H., To, K.K.W., Chu, H., Yang, J., Xing, F., Liu, J., Yip, C.C.Y., Poon, R.W.S., et al. 2020. A familial cluster of pneumonia associated with the 2019 novel coronavirus indicating person-to-person transmission: a study of a family cluster. Lancet 395, 514-523.

Corman, V., Bleicker, T., Brünink, S., Drosten, C., Zambon, M., and Organization, W.H. 2020. Diagnostic detection of Wuhan coronavirus 2019 by real-time RT-PCR. Geneva: World Health Organization 13.

Cutts, T., Grolla, A., Jones, S., Cook, B.W.M., Qiu, X., and Theriault, S.S. 2016. Inactivation of Zaire ebolavirus variant Makona in human serum samples analyzed by enzyme-linked immunosorbent assay. J. Infect. Dis. 214, S218-S221.

Darnell, M.E., Subbarao, K., Feinstone, S.M., and Taylor, D.R. 2004. Inactivation of the coronavirus that induces severe acute respiratory syndrome, SARS-CoV. J. Virol. Methods 121, 85-91.

Decrey, L., Kazama, S., and Kohn, T. 2016. Ammonia as an in situ sanitizer: influence of virus genome type on inactivation. Appl. Environ. Microbiol. 82, 4909-4920. 
ECDC, European Centre for Disease Prevention and Control. 2020. COVID-19 situation update worldwide, as 5 June 2020. https:// www.ecdc.europa.eu/en/geographical-distribution-2019-ncovcases

Gamarnik, A.V. and Andino, R. 1998. Switch from translation to RNA replication in a positive-stranded RNA virus. Genes Dev. 12, 2293-2304.

Herriott, R.M. 1961. Infectious nucleic acids, a new dimension in virology. Science 134, 256-260.

Huang, C., Wang, Y., Li, X., Ren, L., Zhao, J., Hu, Y., Zhang, L., Fan, G., Xu, J., Gu, X., et al. 2020. Clinical features of patients infected with 2019 novel coronavirus in Wuhan, China. Lancet 395, $497-$ 506.

Kim, Y.I., Kim, S.G., Kim, S.M., Kim, E.H., Park, S.J., Yu, K.M., Chang, J.H., Kim, E.J., Lee, S., Casel, M.A.B., et al. 2020. Infection and rapid transmission of SARS-CoV-2 in ferrets. Cell Host Microbe 27, 704-709.

Knight, C.A. 1975. Action of chemical and physical agents on viruses. In Chemistry of Viruses, pp. 180-238. Springer, Berlin, Heidelberg, Germany.

Lamarre, A. and Talbot, P.J. 1989. Effect of $\mathrm{pH}$ and temperature on the infectivity of human coronavirus 229E. Can. J. Microbiol. 35, 972-974.

Larkin, E.P. 1977. Thermal inactivation of viruses. Army Natick Research And Development Center, Massachusetts, USA.

Leclercq, I., Batejat, C., Burguière, A.M., and Manuguerra, J.C. 2014. Heat inactivation of the middle east respiratory syndrome coronavirus. Influenza Other Respir. Viruses 8, 585-586.

Lelie, P., Reesink, H., and Lucas, C. 1987. Inactivation of 12 viruses by heating steps applied during manufacture of a hepatitis $\mathrm{B}$ vaccine. J. Med. Virol. 23, 297-301.

Li, D., Zhang, J., and Li, J. 2020. Primer design for quantitative realtime PCR for the emerging coronavirus SARS-CoV-2. Theranostics 10, 7150-7162.

McDonnell, G.E. 2017. Antisepsis, disinfection, and sterilization: types, action, and resistance. 2nd edn., John Wiley \& Sons, New Sersey, USA.

Nuanualsuwan, S. and Cliver, D.O. 2003. Infectivity of RNA from inactivated Poliovirus. Appl. Environ. Microbiol. 69, 1629-1632.

PAHO, Pan American Health Organization. 2020a. General procedures for inactivation of potentially infectious samples with ebola virus and other highly pathogenic viral agents. https:// www.paho.org/hq/dmdocuments/2014/2014-cha-proceduresinactivation-ebola.pdf

PAHO, Pan American Health Organization. 2020b. Laboratory guidelines for detection and diagnosis of the novel coronavirus (2019-nCoV) infection. https://www.paho.org/en/documents/ laboratory-guidelines-detection-and-diagnosis-novel-coronavirus2019-ncov-infection

Park, S.L., Huang, Y.J.S., Hsu, W.W., Hettenbach, S.M., Higgs, S., and Vanlandingham, D.L. 2016. Virus-specific thermostability and heat inactivation profiles of alphaviruses. J. Virol. Methods 234, 152-155.

Pratelli, A. 2008. Canine coronavirus inactivation with physical and chemical agents. Vet. J. 177, 71-79.

Reed, L.J. and Muench, H. 1938. A simple method of estimating fifty percent endpoints. Am. J. Epidemiol. 27, 493-497.

Roehrig, J.T., Hombach, J., and Barrett, A.D.T. 2008. Guidelines for plaque-reduction neutralization testing of human antibodies to dengue viruses. Viral Immunol. 21, 123-132.

Schlegel, A., Immelmann, A., and Kempf, C. 2001. Virus inactivation of plasma-derived proteins by pasteurization in the presence of guanidine hydrochloride. Transfusion 41, 382-389.

Siddell, S., Wege, H., and Ter Meulen, V. 1983. The biology of coronaviruses. J. Gen. Virol. 64, 761-776.

WHO, World Health Organization. 2003. First data on stability and resistance of SARS coronavirus compiled by members of WHO laboratory network. https://www.who.int/csr/sars/survival_ 2003_05_04/en/

WHO, World Health Organization. 2020a. 2019-nCoV outbreak is an emergency of international concern. https://www.euro.who. $\mathrm{int} / \mathrm{en} /$ health-topics/health-emergencies/international-healthregulations/news/news/2020/2/2019-ncov-outbreak-is-anemergency-of-international-concern

WHO, World Health Organization. 2020b. Coronavirus. https:// www.who.int/health-topics/coronavirus\#tab=tab_2

WHO, World Health Organization. 2020c. WHO Director-General's opening remarks at the media briefing on COVID-19.

Yunoki, M., Urayama, T., Yamamoto, I., Abe, S., and Ikuta, K. 2004. Heat sensitivity of a SARS-associated coronavirus introduced into plasma products. Vox Sang. 87, 302-303. 